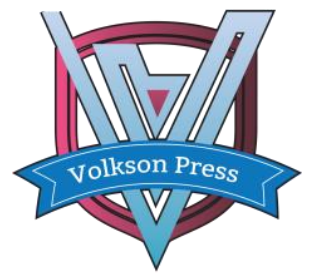

Contents List available at VOLKSON PRESS

Economics \& Management Innovations(EMI)

DOI : http://doi.org/10.26480/icemi.01.2017.220.222

\title{
Women's Rights: Thai Women's Status in Reality
}

\author{
Prutyumon Lepananon ${ }^{1,}$, Yuwaree Choksuansab ${ }^{2}$, and Korakit Choomgrant ${ }^{3}$ \\ 1, 2 Faculty of Tourism and Hospitality, Dhurakij Pundit University, Thailand \\ ${ }^{3}$ Department of History, Faculty of Social Sciences, Kasetsart University, Thailand \\ *prutyumon.uta@dpu.ac.th
}

This is an open access article distributed under the Creative Commons Attribution License, which permits unrestricted use, distribution, and reproduction in any medium, provided the original work is properly cited.

\section{ARTICLE DETAILS}

\section{Article History:}

Received 02 october 2017 Accepted 06 october 2017 Available online 11 october 2017

\section{Keywords:}

Gender Equality, Thailand, Women, Violence, Socialization.

\section{ABSTRACT}

This paper entitled “Women's Rights: Thai Women's Status in Reality” is part of the research project of "The Current Status of the Sustainable Development Goal 5 in The Current Context of Thailand: Gender Equality" and has been designed to employ exploratory and qualitative research method. The data analyzed and synthesized in this paper include relevant statistics and literatures based on the issue of gender equality, particularly the target goal 5.2: Eliminate all forms of violence against all women and girls in public and private spheres, including trafficking and sexual and other types of exploitation. The paper reveals that violence against women and girls exists at high level in Thailand. The status of Thai women is not as accepted as Thai men. The Thai government has shown greater attempts to solve this issue by imposing laws and regulations as well as measures. One of the possible approaches to erase the problem is to tackle with the root cause which is the perception and attitude of gender differences through appropriate socialization processes i.e. formal and informal education.

\section{Introduction}

The study of 'Gender Equality', in terms of the status and roles of Thai women, has been an ongoing concern, particularly when the Thai government has officially ratified and shared its aim to achieve the 17 Sustainable Development Goals: SDGS by 2030, together with a greater number of countries. Researchers are interested in scrutinizing the contemporary status of Goal 5, Gender Equality: Achieve Gender Equality and Empower All Women and Girls, in the context of Thailand. This study aims at examining Thai women's Status regarding violence against women in reality. Researchers are well-aware of the arguments on differences and gender inequality issues that lead to various forms of discriminating practices against women and girls. These have incurred social problems as observed through several channels, and were a source for discourse and debate in the past decades.

To achieve gender equality and acceptance in Thailand is difficult due to the concept of the "two-sex system" which has long been embedded in Thai society. Moreover, it is evident that Thailand is a male-dominated country. As such, women's roles are restricted in certain spaces or places such as in the home. Socially, women are taught to be modest and passive. Women's rights are therefore limited and not equivalent to those of men. To recognize women's roles is possible by only by legislation but by using monitoring mechanisms. In addition, to developing and enhancing the gender equality concept, the socialization process including parenting and formal education must be established to create more understanding. Poverty is also seen as a major cause of the problem which requires immediate attention from the government.

Women-associated data compiled by different government agencies is not well-organized, and it indicates lack of co-operation among government agencies. Moreover, there is no authorized center managing and keeping all upto-date data. However, it is reported by the Department of Family's Affairs and Family Development that the kind of center is going to be formed in the very near future, providing both information related to women, and developing appropriate systematic indicators for more effective analysis.

This research has been designed to use exploratory and qualitative research methods. The data analyzed and synthesized in this research includes relevant statistics and literatures based on the issue of gender equality. This research aimed at developing a greater understanding of the current context of Thailand in relation to Goal 5, evaluating readiness of Thailand to achieve the goal, and prioritizing each target goal. Besides, this research also examined existing Thailand's economic, social and legislative policies, and appropriate practices from different nations. Consequently, this study provides alternative resolutions to the problem related to gender inequality in Thailand.

\section{Characteristics of Thai Women}

The two-sex system or Binary System appeared in Thai society has long been rooted in the country. Although this characteristic has not been recorded, the practices in relation to social norms are evident. Thai men and women's roles and responsibilities are indicators of the division of work by gender. Men take a leading role and act as the breadwinner in the family, while women take care of children, do housework and prepare meals. Historically only men became warriors and soldiers while women were literally protected. According to Chronicles, women possibly joined the army once they disguised as men, such as in a case of Queen Suriyothai. It thus could be interpreted that Thailand is a male-dominated country. The cause of these phenomena can be illustrated by the so-called 'socialization process'. This process has a great impact on men and women's thinking, practices and behavior. It spreads some stereotypes of gender differences and these become perceived collective characteristics in the society. Additionally, it has been strengthened by religious, cultural and traditional beliefs. One case in particularly in Thailand is the Buddhist ordination. Only men can completely become masculine and express his gratitude and uplift his parents to heaven while women cannot participate in similar practice. Women can only be fully feminine by becoming a mother [1]. From this example, it reflects the gender inequality and strict set of knowledge that does not include different sexual orientations (LGBTIQ: Lesbian, Gay, Bisexual, Transgender, Intersexual and Questioning). Consequently, Thai women have long been socially and culturally discriminated and suppressed.

This research discovers that the status of Thai women is gradually being elevated. From many sources including education, healthcare and women development, Thai women's roles are significantly recognized as equal to men in almost every area. The government has launched relevant policies and laws to safeguard and promote women's status and equality; it allows women to stand side by side with men. Overall, gender equality in Thailand is not just a paper, it is socially accepted. Despite the fact that Thai women's status has gained great attention from the government and public, violence against women and girls by men remains unresolved. This can be interpreted as women are still victims of 'gender inequality' and 'perceived collective characteristics of women as modest and passive'. This problem is against Human Rights and urgently needs to be addressed. 


\section{Violence against Thai Women in Reality}

The violence against women and girls (VAW/G) can be physical, psychological, sexual abuse or deprivation. It undoubtedly affects victims' life such as pain, distress, anxiety and so on. In addition, the violence leads to economic and social impacts. The United Nations announced the Declaration on the Elimination of Violence against Women in 1993 and voiced concern about the violence in both public and private spaces. Even though the Declaration has been implemented for over 20 years, it was reported by UN Women (2017) that 35 percent of women worldwide have experienced physical or sexual violence by an intimate partner or a nonpartner [2]. Moreover, 125 million women had forcefully experienced female genital mutilation and around $38 \%$ of women were murdered by their intimate partners [3]. These circumstances have resulted in the target goal 5.2 of SDG 5; eliminate all forms of violence against all women and girls in public and private spheres, including trafficking and sexual and other types of exploitation.

In Thailand, the problem on VAW/G has currently been in severe situation. Referring to UN Women report on Thailand's women and girls in 2013, Thailand was ranked $36^{\text {th }}$ from 75 nations in terms of physical violence against women and girls level, and placed $7^{\text {th }}$ from 71 countries in terms of sexual violence from their intimate partners [4]. It is also reported that women were violated by their intimate partners, boyfriends and other men. The data collected from related agencies, for example One Stop Crisis Center and the Police General Hospital, have presented the increasing number of victims from VAW/G [5,6,7]. Table 1 shows the number of women who were abused and received assistance from One Stop Crisis Center, Ministry of Public Health during 2011 - 2015.

Table 1 Number and Types of Violence against Women collected by One Stop Crisis Center, Ministry of Public Health

\begin{tabular}{|l|l|l|l|l|l|}
\hline Types of violence & $\mathbf{2 0 1 1}$ & $\mathbf{2 0 1 2}$ & $\mathbf{2 0 1 3}$ & $\mathbf{2 0 1 4}$ & $\mathbf{2 0 1 5}$ \\
\hline Physical & 9,816 & 9,654 & 9,699 & 5,731 & 8,915 \\
\hline Sexual & 1,829 & 1,549 & 2,226 & 1,612 & 2,994 \\
\hline psychological & 495 & 490 & 569 & 210 & 896 \\
\hline Abandonment & 96 & 112 & 89 & 108 & 389 \\
\hline $\begin{array}{l}\text { Trafficking and } \\
\text { exploitation }\end{array}$ & 39 & 84 & 64 & 5 & 77 \\
\hline Total & $\mathbf{1 1 , 0 7 4}$ & $\mathbf{1 0 , 8 6 9}$ & $\mathbf{1 2 , 6 3 7}$ & $\mathbf{7 , 6 6 6}$ & $\mathbf{1 3 , 2 7 1}$ \\
\hline
\end{tabular}

In Thailand, VAW/G is caused by many factors. Firstly, there has been inequality among men and women. Some Thai men perceive their superior power and status, and treat women as an object, as stated in the previous part. In some families, a wife financially relies on husband. As a result, she does not have negotiating power and must unwillingly live with the husband. Education on gender equality is insufficient. Many Thai people still believe that domestic violence is personal, which non-family members should not take part in. Meanwhile, victims misunderstand that being abused is embarrassing, therefore they keep it silent. Many of them tolerate living with the partner and being abused. Another cause is that Thai society has rapidly changed to be more materialism, in which some parents aim at having wealth rather than cultivating their children.

This research reveals that there are many factors causing inadequate results to solve the problems including human resources, complicated family affairs, less collaboration between relevant agencies and ineffective legislation. To explain, officials lack knowledge and skills, laws aim at reconciling differences, the existing mechanism is not properly working, the criminals are not suitably rehabilitated. One of the most noticeable weaknesses of the jurisdiction is the access to the process. To achieve the target goal 5.2, the following suggestions are made below;

1. Amend the Protection of Domestic Violence Victims Act to use a positive based approach and include provision in social services and funds to support women affected from domestic violence [8].

2. Increase the numbers of female investigators at every police station and develop Standard Operating Procedure for police officer for the protection of women from violence to reduce the gap in law enforcement [8].

3. Enhance monitoring, assessment, health care, recovery, assistance with gender sensitivity. Train personnel with the knowledge of gender and gender perspectives using interdisciplinary approaches so that social workers can be more gender sensitive.

4. Increase financial and resource support for shelters for women affected by violence. Create extensive and sufficient protection for victims of violence.

5. Develop appropriate guidelines for police to identify trafficked persons according to the Law and create an effective complaint mechanism that is easy to access [9].

6. Establish a watch dog system in the community with assistance from the government to facilitate the working process.

7. Create a center for national violence data that links with all relevant government and private agencies

8. Encourage the society to pay attention to violence and change the perception of ignorance of one's family affairs. Change the attitude of the male-domination to gender equality. Respect Human Rights. All of these should be continuously discussed with youth. Special attention should be given to the risk areas such as slum.

9. Promote the available channels in case women need help such as application on any smartphone and use popular social media to reach the youth.

10. Add gender equality content such as sexual morals, good parenting, women and children rights and gender studies into the curriculum.

\section{Final Observation}

The comments made by non-government organizations address that the solutions, policies and measures are not sustainable because it only decreases a number discriminated, violated and trafficked women. However, this research shows that the government focuses not only on a short-term outcome but also on long-term plans. This paper suggests that both long and short-term plan should be disseminated to NGOs. Both parties should work closely as policy makers and insiders.

The prioritization should be given to target goal 5.2, evaluated from the statistical facts and analyses presented above. Overall, the question of violence in Thailand is of great concern. The number of women abused by their intimate partners is significantly high. Noticeably, a number of women who are violated by the male strangers are lower than those by family members or relatives. This circumstance reflects the gender inequality in Thailand because of its strong embedded two-sex perception and male-dominant characteristics. To achieve a sustainable result, the amendment of the education and poverty reduction is suggested. These two approaches would produce exceeding understanding and respect of different genders.

\section{Conclusion}

This study reveals that Thailand has paid greater attention to gender equality issues and elimination of all forms of violence against women and girls. Working procedures and plans have been periodically established to form social protection for women and girls. The Gender Equality Act imposed in 2016 is evident and indicates the attempt of the Thai government to guarantee the true equality for all genders including LGBTIQ. It might be considered as a top-down action but it is a consequence of long-lasting public fight for Human Rights.

Lastly, the definition of gender equality in SDG 5 should cover LGBTIQ groups and boys because these people are also sensitive to the two-sex system, particularly the LGBTIQ group. By indicating the status of Thai women, many problems are specified. It would be doubled for LGBTIQ group that is excluded from the two-sex system. To achieve the sustainable gender equality, the indicators should be revised to measure all sensitive groups of people. This needs another research for the better outcome.

\section{References}

[1] Choomgrant, Korakit. (2009) Expression of Sexuality and Lifestyles in Singapore and Bangkok: A Case of Singaporean Homosexual Men. M.A. Thesis, Centre for East and South-East Asian Studies, Lund University.

[2] UN Women. (2017). Facts and figures: Ending violence against women. Available at http://www.unwomen.org/en/what-we-do/endingviolence-against-women/facts-and-figures. Retrieved on 10 May 2017.

[3] World Bank. (2017). Violence against Women and Girls. Available at http://www.worldbank.org/en/topic/socialdevelopment/brief/violence -against-women-and-girls. Published on 12 January 2017.

[4] Association for the Promotion of the Status of Women. (2017). Thailand and Violence against Women and Children Problem. Available at http://www.apsw-thailand.org/stopviolence57.html. Retrieved on 30 
May 2017.

[5] Bureau of Health Administration, Ministry of Public Health. (2014). Statistics on Service Receivers of One Stop Crisis Center during 20112013. Available

at http://phdb.moph.go.th/phdb2017/force down.php?f id=22. Retrieved on 21 May 2017.

[6] Department of Women's Affairs and Family Development, Ministry of Social Development and Human Security. (2015). Report on Domestic Violence Situation 2014. available at http://www.violence.in.th/publicweb/pdf/M17/M172557.pdf. Retrieve on 27 May 2017.

[7] Department of Women's Affairs and Family Development, Ministry of Social Development and Human Security. (2016). Report on Domestic
Violence

Situation

2015.

Available at http://www.violence.in.th/publicweb/pdf/M17/M172557.pdf. Retrieve on 27 May 2017.

[8] National Human Rights Commission of Thailand. (2017). Alternative Report on Thailand's Implementation in Compliance with the Convention on the Elimination of All Forms of Discrimination against Women (CEDAW) by the National Human Rights Commission of Thailand. Available at http://www.nhrc.or.th/News.Retrieve on 1 June 2017.

[9] Thai Women's CSOs. (2014). Summary report of Thai Women's CSOs on Beijing +20 Review. available at http://www.socialwatch.org/sites/default/files/THAI-CSO-ReportBeijing-review-eng.pdf. retrieve on 12 May 2017. 